\title{
近赤外励起ナノ蛍光体のバイオメディカルイメージング応用
}

\author{
曽我公平
}

\section{Application of Nanophosphors with Near Infrared Excitation for Biomedical Imaging}

\author{
Kohei Soga \\ Department of Materials Science and Technology, Tokyo University of Science; \\ 2641 Yamazaki, Noda, Chiba 278-8510, Japan.
}

(Received August 3, 2012)

\begin{abstract}
Fluorescence bioimaging is an inevitable method for biological, medical and pharmaceutical sciences to visualize substances in biological objects in a highly sensitive, multicolor and dynamic way. Recently, elongation of the fluorescence wavelength is a trend used in this imaging to suppress scattering, which limits the imaging depth to within several millimeters. It has been known that the so-called "biological window" with low loss for a biological tissue has been known to lie in the near-infrared (NIR) wavelength range between 1000 and $1700 \mathrm{~nm}$. The use of fluorescence in the over-1000-nm (OTN) NIR can deepen the observation to several centimeters. The use of imaging devices based on semiconductor silicon has limited the wavelength of the fluorescence bioimaging to less than $1000 \mathrm{~nm}$. However, the appearance of InGaAs CCD on the market, to allow for imaging of the OTN-NIR light, is now changing the situation. On the other hand, rare-earth doped ceramic nanophosphors (RED-CNP) can emit efficient fluorescence in the OTN-NIR wavelength range. The author's group has applied the RED-CNP to OTN-NIR fluorescence bioimaging by hybridizing the RED-CNP with various polymers or molecules. The present paper will review the development of the materials and systems for this OTN-NIR fluorescence bioimaging, together with some applications of the imaging method for biological research and a medical surgery.
\end{abstract}

Key words_— bioimaging; fluorescence; near infrared; rare-earth; ceramic

\section{1.はじめに}

蛍光バイオイメージングは，高感度，多色で動態 観察が可能な生体内の物質の可視化方法として，生 物学, 医学, 薬学の研究や診断において不可欠な技 術となっている。これまで用いられてきた波長域は 主に紫外光を励起光とした可視蛍光であり，蛍光体 の退色, 生体への毒性, 自家蛍光などの様々な問題 を抱えている.1）観察深度を浅くし，像にボケをも たらす光散乱は可視光近傍の波長域では短波長ほど 強い. 特にin vivo イメージングでは励起波長や蛍 光波長が短いためにその観察深度は数 $\mathrm{mm}$ が限界 とされてきた。近年ではこれらを鑑み，励起波長や 蛍光波長の長波長化が 1 つのトレンドであり，indocyanine green (ICG) 2) や量子ドット3)などの優れ

The author declares no conflict of interest.

東京理科大学基礎工学部材料工学科（T278-8510 千葉 県野田市山崎 2641)

e-mail: mail@ksoga.com

本総説は, 日本薬学会第 132 年会シンポジウム S24 で

発表したものを中心に記述したものである.
た蛍光体の開発により $900 \mathrm{~nm}$ 付近の近赤外（near infrared；NIR）蛍光を用いた in vivo イメージング が実現している。しかし，上述のように光散乱の観 点からはさらに長波長でのイメージングが望まし い. 生体において透過率の高い「生体の窓」4) 1000-1700 nm の波長域に存在し, $1000 \mathrm{~nm}$ を超える 波長の近赤外光（over-1000-nm near infrared; OTNNIR）のイメージングへの応用に期待が集まりつつ ある. 最も一般的に用いられている $\mathrm{Si}$ の CCD 力 メラでは長波長限界は $1000 \mathrm{~nm}$ 付近であるが, 近 年 InGaAs CCD が実用化されてきており，上記の OTN-NIR における蛍光バイオイメージングが現実 味を帯びてきた，筆者らは OTN-NIR 蛍光バイオイ メージングに一早く着目し, 希土類含有セラミック スナノ粒子 (rare-earth doped ceramic nanophosphor; RED-CNP）を蛍光体としたイメージングに世界に 先駆けて成功している。本稿では，動物の皮下数 $\mathrm{cm}$ のイメージングが可能な OTN-NIR 蛍光バイオ イメージングシステムとそのための材料の開発につ 


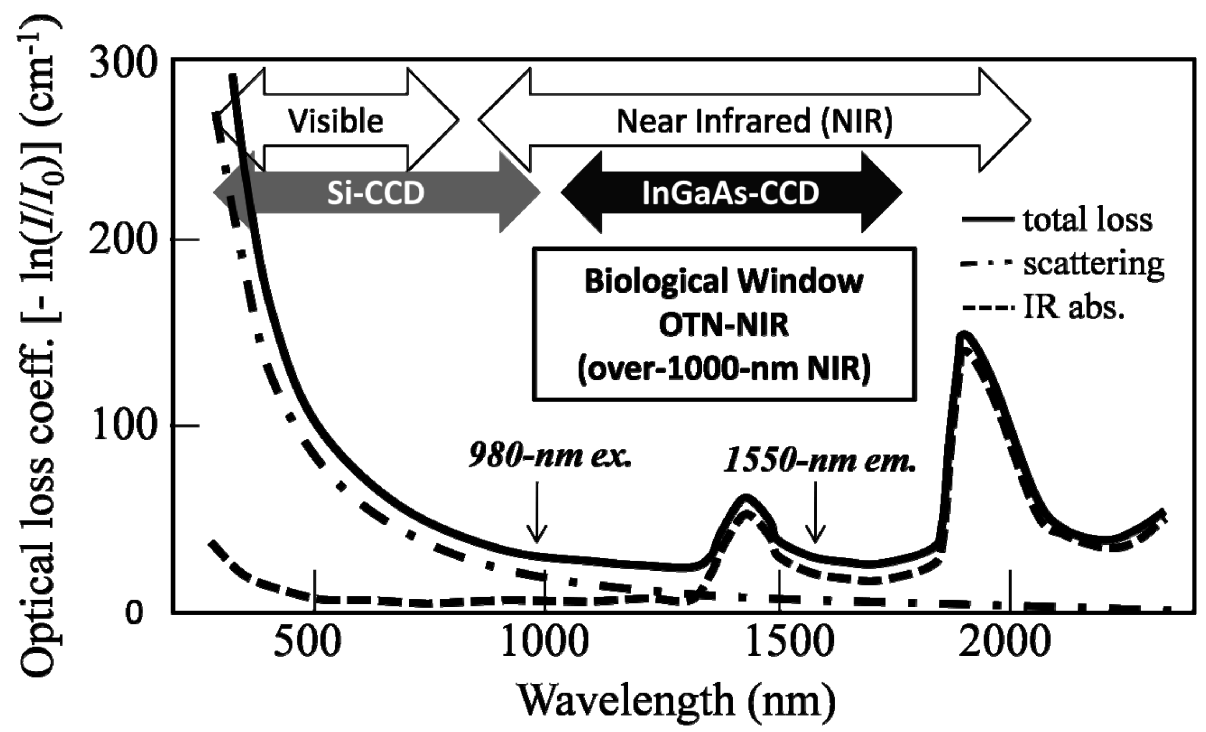

Fig. 1. Optical Loss of Human Skin and the Biological Window ${ }^{5)}$

The window is the valley of the spectrum formed by the tails of the scattering and infrared absorption. The window matches the detectable wavelength of InGaAs CCD.

いて総説する.

\section{2.「生体の空」とOTN-NIR}

物質の光損失は根本的には光散乱と光吸収で決ま る．紫外〜赤外に渡る領域では，紫外・可視で起こ る電子励起による光吸収，一般に短波長ほど強い光 散乱，長波長ほど強い分子内振動に伴う分極振動の 励起による赤外吸収が考えられる。光散乱に関して は原子や分子，イオンによって起こるレイリー散乱 と屈折率界面で起こるミ一散乱が混在しているが, いずれにしてもたいていの生物試料で光散乱による 損失は短波長に向けて急激に立ち上がってゆく，可 視域での光損失はこの光散乱と色素による電子遷移 吸収によって決定づけられ複雑である。しかし，こ れらの光散乱と光吸収は $800 \mathrm{~nm}$ 以上の NIR 波長 域へ向けて急激に減少する。一方，長波長側の赤外 吸収は $2000 \mathrm{~nm}$ 以上では非常に大きな損失寄与が あるが，2000 nm から短波長側へ向けて急激に減少 する. Figure 1 に典型的な例としてヒトの皮膚の光 損失スペクトルを示す. 5) 筆者らが様々な生物試料 に関して測定を行ってみると，NIR 域に関して短 波長側の損失は概ね同様であるが，厳密には長波長 側の赤外吸収は含水率の影響を受けて変化する。し かし多くの生体試料で Fig. 1 のような損失プロフ アイルであると考えてよい. 上述のように現在の蛍 光バイオイメージングは ICG や量子ドットを用い て $900 \mathrm{~nm}$ 付近の比較的損失の小さい波長域で行わ
れつつあるが，さらに長波長の $1000 \mathrm{~nm}$ 以上の近 赤外 (over-1000-nm near infrared; OTN-NIR) に蛍 光波長を移動し，縦軸が対数となっていることに注 意すると，大幅な観察深度の増大が期待される．し かし，これまで用いられてきたカメラの多くが半導 体シリコンを用いたものであり，シリコンのバンド ギャップが $1100 \mathrm{~nm}$ に相当する $1.1 \mathrm{eV}$ であること から観察波長域は約 $1000 \mathrm{~nm}$ が限界である。それ より長波長の蛍光を用いたバイオイメージングは筆 者らが行った研究以前は行われることがなかった。 近年，シリコンを用いた CCD に加え， InGaAs を 用いた CCD が比較的容易に手に入るようになった。 InGaAs CCD は，800-1700 nm の OTN-NIR におけ るイメージングが可能であり，この CCD を用いて 適切なイメージングシステムを開発すれば，従来の システムを遥かにしのぐ深部の観察が可能なイメー ジングシステムが実現するとの期待が高まってき た。このためには，まず OTN-NIR 波長域において 良好な発光を示す蛍光体プローブの開発が不可欠で

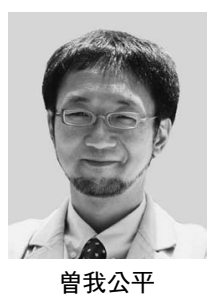

1995 年 3 月東京大学大学院工学系研究 科材料学専攻博士課程修了, 博士（工 学) 取得. 現在, 東京理科大学基礎工 学部材料工学科教授. 同大学総合研究 機構がん基盤科学技術研究センター VRG グループリーダー．希土類含有セ ラミックスの様々なフォトニクス応用 とプロセスを手掛ける. 
ある。

\section{3. 希土類含有セラミックスと NIR 蛍光}

3 価の希土類イオンを含有するセラミックスは, 4f 電子遷移による蛍光を示すことが知られてい る．鉄や銅に代表される遷移金属イオンの電子遷移 が最外殼の $\mathrm{d}$ 電子軌道内で起こるのに対し, 希土 類イオンで電子遷移が起こる $4 \mathrm{f}$ 電子軌道は, 最も エネルギーが高いために部分的に空軌道を有するに もかかわらず最外殼ではなく, さらに外側に存在す る充満した $5 \mathrm{~s}^{2} 5 \mathrm{p}^{6}$ 軌道の電子により遮蔽されてい る.このため, スペクトルの広がりや準位のシフ 卜，熱緩和をもたらす，外部のイオンや分子からの 動的, 静的な電場の影響は, 典型的な遷移元素の場 合よりも小さい. したがって，3 価の希土類イオン の $4 \mathrm{f}$ 電子遷移は固体中においてもエネルギー準位 幅が原子スペクトル並みに狭く, 励起準位寿命が長 いことを特徵としている.6,7)これらの特徵により 3 価の希土類イオンをドープしたセラミックスは既に 実用的に用いられている。例えば $\mathrm{Nd}^{3+}$ をドープし たイットリウムアルミニウムガーネット（yttrium aluminum garnet; YAG) は $800 \mathrm{~nm}$ の NIR 光を励起 光として $1064 \mathrm{~nm}$ の OTN-NIR 光を発する高出力 固体レーザーの代表格として知られている. ${ }^{8)}$ また, $\mathrm{Er}^{3+}$ をドープした石英系ファイバーは $980 \mathrm{~nm}$ の NIR 光を励起光として $1550 \mathrm{~nm}$ の OTN-NIR 光を 発することによる光ファイバー信号増幅器に用いら れて長距離光ファイバー通信において活躍してい る. 9)さらには，狭い準位幅と離散的なエネルギー 準位構造，比較的弱い熱緩和により，3 価の希土類 イオンをドープした特定のセラミックスは NIR 光 を励起光として可視光を発するアップコンバージョ ン (upconversion; UC) 発光を示すことが知られて いる. Figure 2 にUC 発光のスキームを示す. ${ }^{10)}$ 上 記の NIR 光を励起光とした NIR 発光では図中の (c) のように通常の蛍光スキームにより発光するが,

$U C$ 発光では (a)や (b)のように長い励起寿命のため に電子が励起状態に留まっている間に 2 段階目，3 段階目の励起が起き, NIR 励起光よりもエネル ギーが高く，波長が短い可視光や紫外光の発光が可 能になる. ${ }^{11,12)} \mathrm{UC}$ 発光では発光が可視発光である ため, 励起光源を半導体レーザーに変更するだけで 従来の可視光用の撮像システムが使えるメリットが ある. 励起光を紫外光や短波長可視光から NIR 光

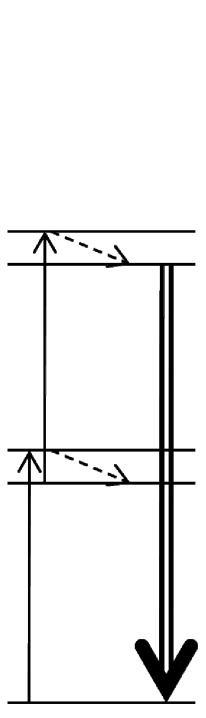

(a)

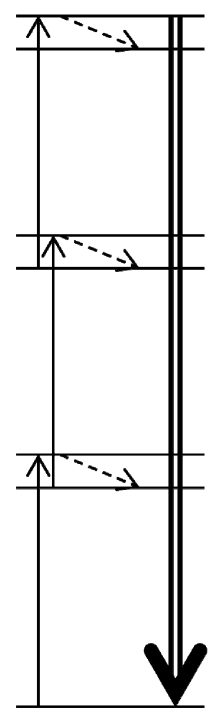

(b)

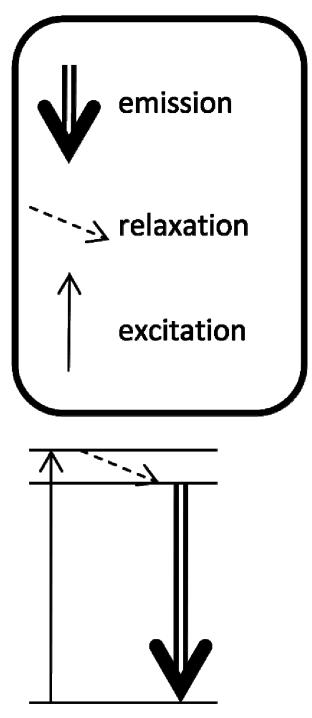

(c)
Fig. 2. Excitation and Emission Processes for Visible Upconversion ( $a, b)$ and Normal NIR Emission (c) under NIR Excitation $^{10)}$

に変更することにより励起光の光散乱, 光毒性, 色 素の退色，自家蛍光など現在の蛍光バイオイメージ ングの様々な問題を解決することができるため, 1990 年代後半よりバイオイメージングへの応用が

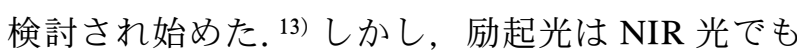
依然蛍光が可視光領域に存在するために強い散乱を 受けること, 多段階励起のために通常蛍光の NIR 発光よりは励起光率が低いことから，筆者らは NIR 励起 NIR 発光を用いた方が断然有利であるこ とに着目し，蛍光プローブの開発と同時に InGaAs CCD カメラを搭載した蛍光バイオイメージングシ ステムの製作に着手した.

\section{OTN-NIR 蛍光バイオイメージングシステム}

現在の蛍光バイオイメージングのシステムには大 別して細胞などを観察する顕微蛍光バイオイメージ ングシステムとマウスなどの小動物などを生きたま ま観察する in vivo 蛍光イメージングシステムがあ る.いずれのシステムにおいても NIR 励起光とし て半導体レーザーを搭載することと, 撮像器として InGaAs CCD カメラを搭載することが必要である が,さらに光量を上げるためのレンズの反射防止 コーティングの最適化, 励起光を遮断する特殊フィ ルターの搭載が必要となる． Figure 3 に筆者らが製 作した OTN-NIR 顕微蛍光バイオイメージングシス テムによる世界初の OTN-NIR 蛍光バイオイメージ 
(a)

(b)

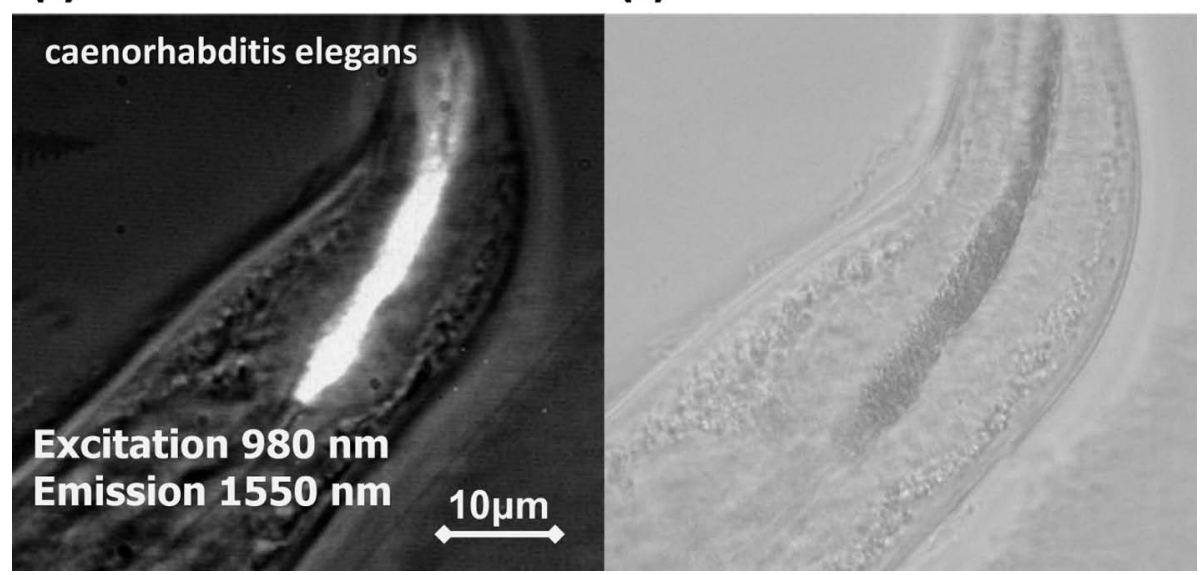

Fig. 3. Bright Field (a) and NIR (1550 nm) Fluorescence (b) Images of Caenorhabditis elegans at $980 \mathrm{~nm}$ Excitation ${ }^{14)}$

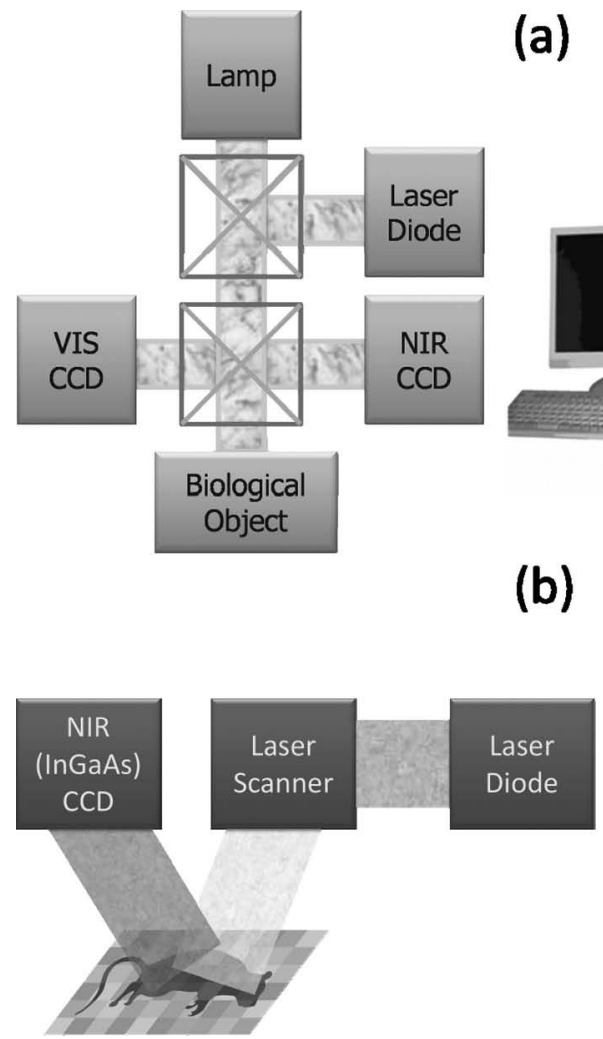

(a)

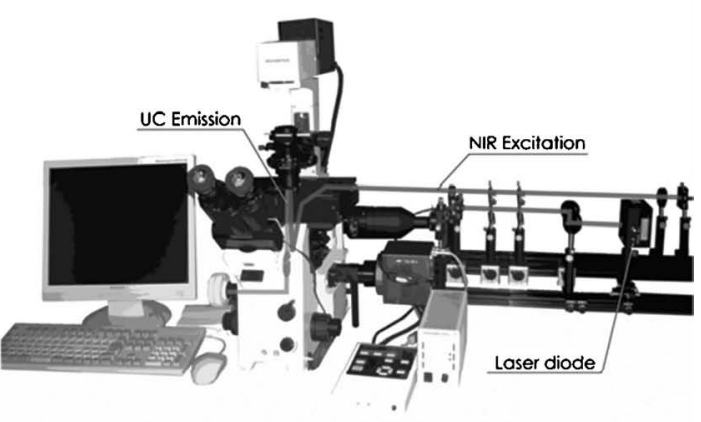

(b)

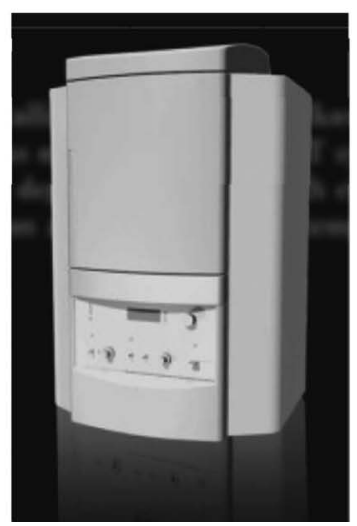

Fig. 4. OTN-NIR Bioimaging Systems

OTN-NIR microscopic fluorescence bioimaging system (a) and OTN-NIR in vivo fluorescence bioimaging system (NIS-OPT, Shimadzu Co.) (b) ${ }^{10)}$

ングの例を示す. ${ }^{14)}$ RED-CNP として Er をドープ した $\mathrm{YPO}_{4}$ を餌とともに食した線虫の消化管のイ メージング像である. 励起光として NIR 光を用い ているため線虫は強い励起光の下でも生きたまま撮 像でき，極めて明るい蛍光像が得られている，一方， in vivo 蛍光イメージングシステムについては NISOPT という装置を島津製作所と共同で開発した
(Fig. 4).イメージングの例としてマウスの脳幹に 注射した RED-CNP (Er ドープ $\left.\mathrm{Y}_{2} \mathrm{O}_{3}\right)$ の OTN-NIR in vivo 蛍光イメージング像を Fig. 5 に示す. ${ }^{15)}$ 頭 蓋を開かず，皮膚も切開せずに極めて明瞭に蛍光像 が観察されている。別途行った実験では筋肉下 3 $\mathrm{cm}$ の蛍光体が観察可能であることが証明されてお り, 現在の in vivo 蛍光イメージングの限界が数 

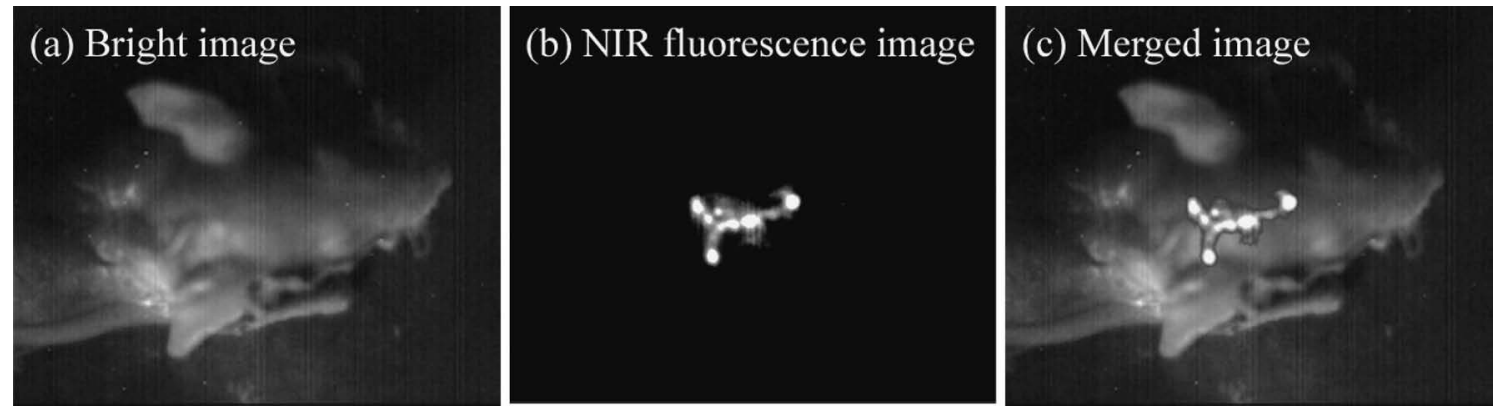

Fig. 5. OTN-NIR Fluorescence Imaging of the Brain Stem of a Mouse $\mathrm{Y}_{2} \mathrm{O}_{3}: \mathrm{Er} / \mathrm{Yb}$ nanoparticles dispersed in PBS buffer were injected through palatine. ${ }^{15}$

mm であることを考えると䪊的な進歩であると言 える.

5. バイオイメージング蛍光体としての REDCNP

バイオイメージングのための蛍光体としての RED-CNP への要求の第一は, 粒径が 10-500 nm 程度の単分散体であることである. バイオイメージ ングに用いるためには生理環境に相当する 0.15 $\mathrm{mol} / \mathrm{L}$ 以上のイオン強度の水溶液中で，単分散状 態を維持できる必要がある，粒径が $500 \mathrm{~nm}$ を超え ると，ハンドリングの最中に粒子が沈降を起こし， 分散状態を維持することが難しい。 また，希土類イ オンは水分子や有機分子と直接触れると励起状態が 緩和してしまうため, 最低 $5 \mathrm{~nm}$ 以上の厚さのセラ ミックスにおおわれている必要があり，これらの要 件からまずは 10-500 nm 程度という条件が設定さ れる，細胞の表面を染めたり，消化器官をイメージ ングする目的では数百 $\mathrm{nm}$ の粒径のものが分散安定 性を得やすくハンドリングが容易だが，マウスの血 中に滞留させたり, 細胞にエンドサイトーシスで取 り込ませたりするためには $100 \mathrm{~nm}$ 以下の粒径が必 要となる. ${ }^{16,17)}$ また, 粒子毎にほぼ均一な発光強度 を示すために粒径の均一性も重要な要素となる。

筆者らは RED-CNP として良好な NIR 励起蛍光 を示す $\mathrm{Y}_{2} \mathrm{O}_{3}$ について均一沈殿法や酵素沈殿法を用 いることにより 20-500 nm の均一粒径の $\mathrm{Y}_{2} \mathrm{O}_{3}$ の作

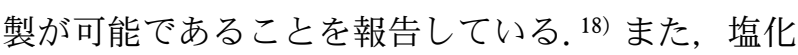
物を出発原料としたコアシェル製法というユニーク な作製方法により数十 nm の粒径の RED-CNP で ある $\mathrm{LaOCl}$ を作製できる. ${ }^{19)} \mathrm{UC}$ 発光のバイオイ メージングを目的として $10 \mathrm{~nm}$ 程度の粒径で作製 が行われてきた $\mathrm{NaYF}_{4}$ ナノ粒子も, OTN-NIR 蛍
光バイオイメージングで同様に用いることができ る. ${ }^{15,20)}$

6. バイオイメージングのための RED-CNP の生 体機能化

6-1. RED-CNP の生体機能化の必要性 ほと んどのセラミックスナノ粒子は表面に正か負の電荷 を持っており，純水中ではシングルナノで作製して も分散状態が得られる。しかし，生体環境に相当す るイオン性の水溶液では, 表面にイオンをまとうこ とで表面電荷が打ち消され，特に数百 $\mathrm{nm}$ 以下の粒 径の粒子の場合はその大きな比表面積による表面エ ネルギーを減らすために凝集し，沈降してしまう。

これを防ぐためには親水性高分子を表面に導入する ことにより高分子の立体反発を利用して分散状態を 維持しなければならない。 また，バイオイメージン グでは標的とする物質のみに付着して蛍光性を持た せる必要があり，他の部位に粒子が付着して蛍光を 発することは望ましくない。したがって非特異的に 細胞や生体の各部に付着することがないように工夫 する必要がある.さらには標的特異的な相互作用に よって特定の細胞や組織に蛍光性を付与するために はリガンド分子や抗体が機能し得る状態で粒子の表 面に導入されなければならない。筆者らは立体反発 による粒子の分散安定化と細胞や生体との非特異的 な相互作用の抑制に効果があり, 毒性が低いことで 知られるポリエチレングリコール (polyethylene glycol; PEG）を粒子表面に様々な方法により導入 している．血管造影などを目的とする場合は PEG の導入のみで十分であるが，さらに特異的な相互作 用を付与するために有効な分子の導入も行っている.

Figure 6 に RED-CNP の様々な表面修飾スキーム をまとめる。 ${ }^{21,22)}$ 以下にこれら各スキームを用いた 


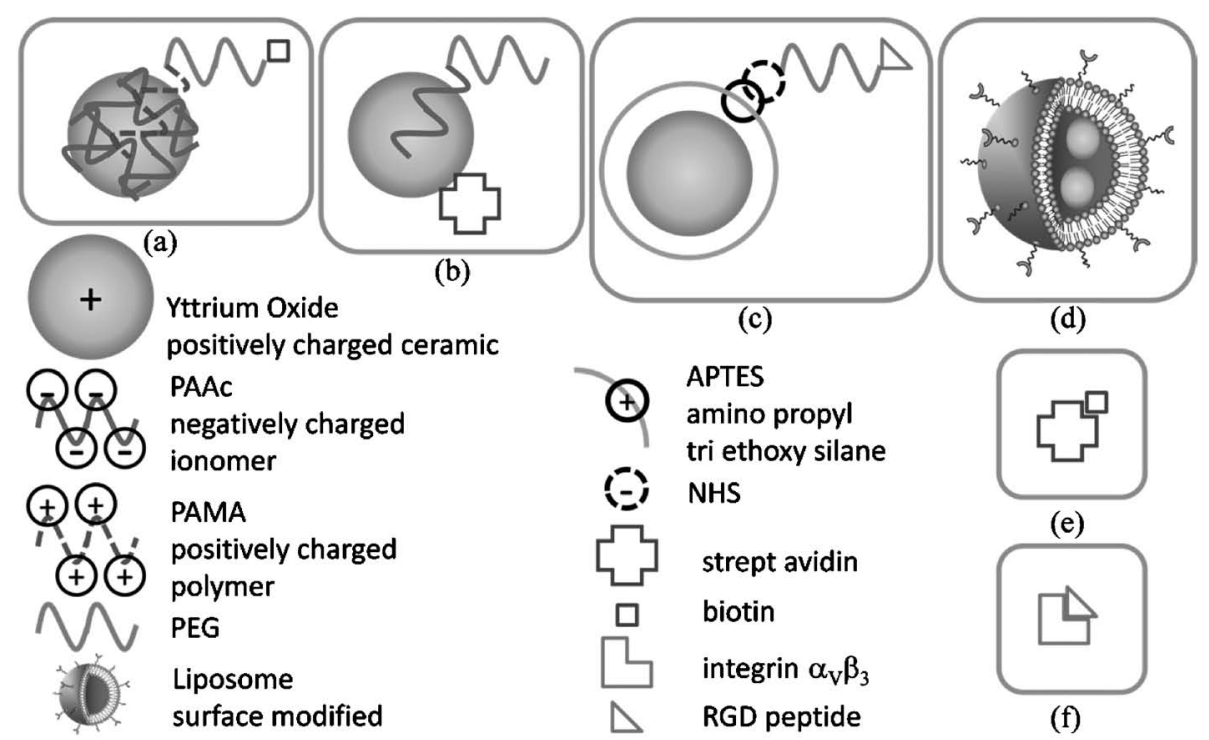

Fig. 6. Various Schemes for the Surface Modification of RED-CNP by Biofunctional Polymers and Ligand Molecules ${ }^{20,21)}$

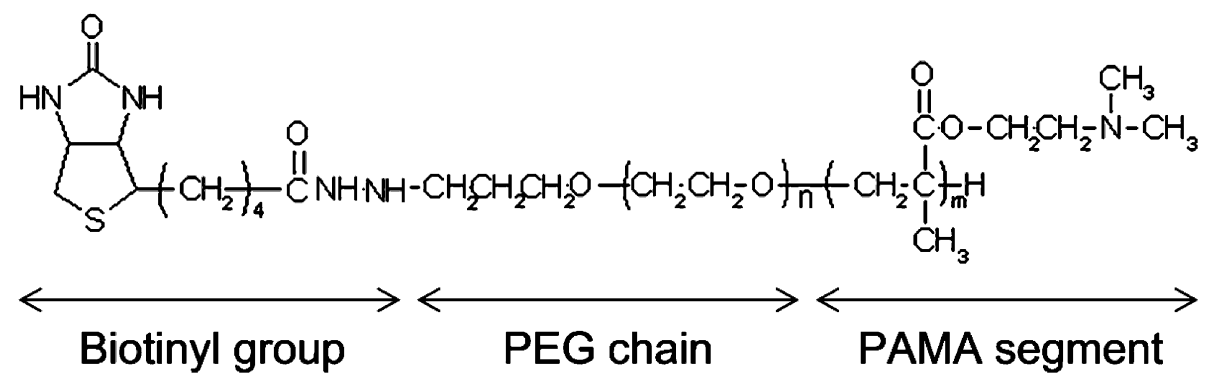

Fig. 7. Structural Formula of Biotinyl-PEG- $b$-PAMA ${ }^{14)}$

表面修飾について解説する.

\section{6-2. アイオノマーと PEG のブロック共重合体} を用いる方法ＲED-CNPとして最も粒径制御性 が高く筆者らが様々な合成方法を検討してきた $\mathrm{Y}_{2} \mathrm{O}_{3}$ ナノ粒子の表面は中性条件では正に帯電するこ とが知られている. 一方, Fig. 7 に示した biotinylPEG- $b$-poly (2-( $N, N$-dimethylamino) ethyl methacrylate)（biotinyl-PEG- $b$-PAMA）は酸性では正に, アルカリ性では負に帯電し得るイオン性高分子（ア イオノマー）である PAMA 鎖と PEG のブロック 共重合体であり，さらに PEGの末端にストレプト アビジンと相互作用するビオチンを有している。筆 者らはまず $\mathrm{Y}_{2} \mathrm{O}_{3}$ ナノ粒子表面を負に帯電するカル ボキシル基の連鎖からなるポリアクリル酸（poly (acrylic acid)；PAAc）で被覆し，この負の電荷と PAMA の正の電荷との相互作用により, PEG 末端 にビオチンを有する表面修飾を施した Er ドープ $\mathrm{Y}_{2} \mathrm{O}_{3}$ ナノ粒子を作製した. Figure 6 ではスキーム （a）に相当する．この修飾方法を用いると，生理食 塩水やバッファー中などの生体環境に相当するイオ ン強度の水溶液で高い分散安定性を示すとともに,

Fig. 8 に示すようにストレプトアビジンと選択性の

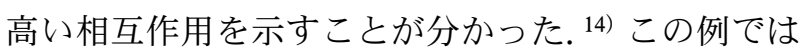
負に带電した PAAc と正に带電した PAMA の二重 のアイオノマーで修飾しているが，さらに単純かつ 簡便な修飾を行うために，負に帯電するPAAc と PEG とのブロック共重合体である PEG- $b$-PAAc に よる $\mathrm{Er}$ ドープ $\mathrm{Y}_{2} \mathrm{O}_{3}$ ナノ粒子の直接的な表面修飾 を試みた。この際，特異的な相互作用を導入するた め，上記の例とは逆にストレプトアビジンを粒子表 面に吸着させた. ${ }^{23)}$ これは Fig. 6 ではスキーム (b) に相当する. Figure 9 に示すように, このような修 飾スキームでも $\mathrm{Y}_{2} \mathrm{O}_{3}$ ナノ粒子は良好な分散安定性 とビオチンとの特異的な相互作用を示すことが明ら かになった. ${ }^{15)}$ 近年では PAAc とは異なる負に帯電 するアイオノマーブロックとして poly (4-vinylben- 

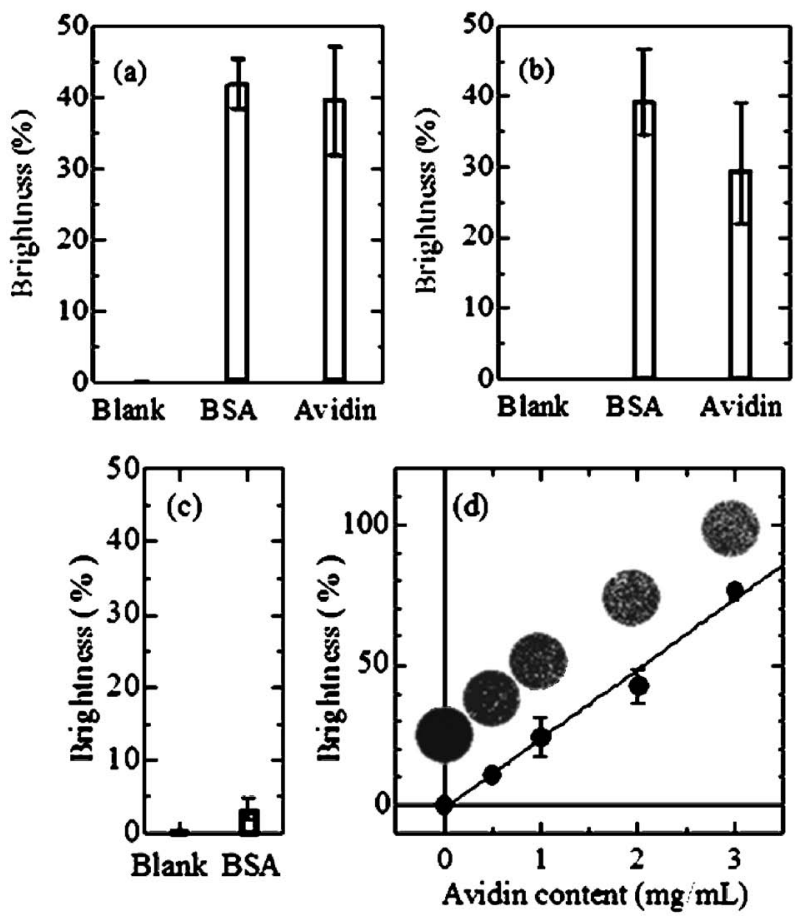

Fig. 8. Specific Interaction of $\mathrm{Y}_{2} \mathrm{O}_{3}$ Nanoparticles Modified with Biotinyl-PEG- $b$-PAMA

UC emission intensities from the blank, BSA and avidin plates soaked in sample suspension (a) Y, (b) YA and (c) YAPB. Fig. (d) shows the relation between the concentration of the avidin for preparing the avidin plate and the UC emission intensity. The UC emission was measured under 980-nm LD laser excitation by monitoring 550-nm UC emission with a fluorescent microscope. The protein plates (a)-(c) were prepared with $3 \mathrm{mg}$ $/ \mathrm{mL}$ protein solution. ${ }^{14}$

zylphosphonate）（PVBP）と PEG とのブロック共 重合体である PEG- $b$-PVBP の合成とその OTNNIR in vivo バイオイメージングへの応用が報告さ れている. ${ }^{24)}$ Figure 10 に PEG- $b$-PVBP により表面 修飾を施した Er ドープ $\mathrm{Y}_{2} \mathrm{O}_{3}$ ナノ粒子を用いた, OTN-NIR in vivo 蛍光バイオイメージングの例を 示す.

\section{6-3. シランカップリング剂を用いる方法}

Figure 6 のスキーム (c) では, $\mathrm{Y}_{2} \mathrm{O}_{3}$ ナノ粒子表面 の $\mathrm{Y}-\mathrm{OH}$ とアミノプロピル基を有するシランカッ プリング剂である 3-aminopropyltrimethoxysilane （APTES）との脱水縮合により，粒子表面にアミノ 基を導入し，さらに片末端にアミド結合のための $N$-hydroxysuccinimide（NHS）を持ち，もう一方に RGD ペプチドを導入するためのマレイミド (maleimide; MA）を持つ PEG， NHS-PEG-MA を反応 させることで，RGD ペプチドを末端に有する PEG を $\mathrm{Y}_{2} \mathrm{O}_{3}$ ナノ粒子表面に導入している. ${ }^{25,26)}$ この方 法では粒子表面にアミノ基を導入するため, NHS-

\section{Biotinylated antibody plate}

(A)

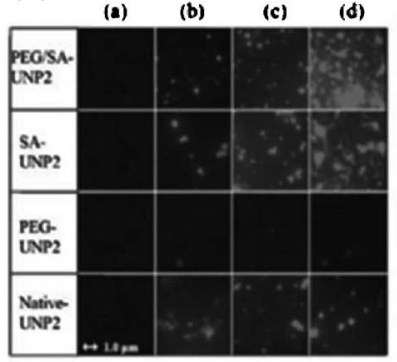

(C)

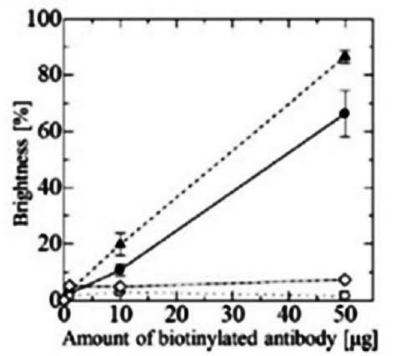

(B)

Linbiotinylated antibody plate

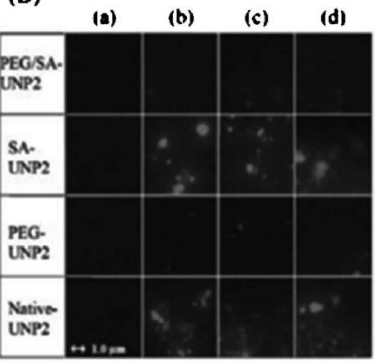

(D)

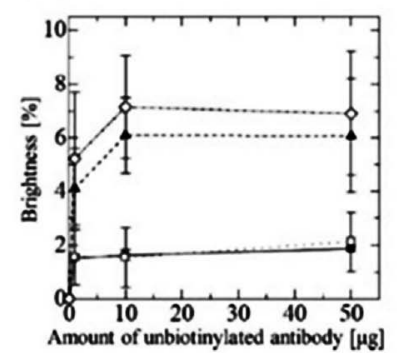

Fig. 9. Specific Interaction of $\mathrm{Y}_{2} \mathrm{O}_{3}$ Nanoparticles Modified with PEG/Avidin

(A) Upconversion luminescence of surface-modified $\mathrm{Y}_{2} \mathrm{O}_{3}$ nanoparticles on a biotinylated antibody plate. (a-d) Biotinylated antibody plate containing $0,1,10$, and $50 \mu \mathrm{g}$ of antibody, respectively. (B) Upconversion luminescence of surface-modified particles on an unbiotinylated antibody plate. (ad) Unbiotinylated antibody plate containing $0,1,10$, and $50 \mu \mathrm{g}$ of antibody, respectively. (C) Numeric analysis result of the upconversion luminescence of surface-modified UNP2s on the biotinylated antibody plate: (O) PEG/ avidin, ( $(\mathbf{\Delta})$ avidin, $(\square)$ PEG and $(\diamond)$ native $\mathrm{Y}_{2} \mathrm{O}_{3}$. (D) Numeric analysis result of the upconversion luminescence of surface-modified $\mathrm{Y}_{2} \mathrm{O}_{3}$ nanoparticles on the unbiotinylated antibody plate. ( $\mathrm{O}$ ) PEG/avidin, ( $\boldsymbol{\Delta}$ ) avidin, $(\square) \mathrm{PEG}$ and $(\diamond)$ native $\mathrm{Y}_{2} \mathrm{O}_{3}$. (Fluorescence microscopy observation: excitation wavelength, $980 \mathrm{~nm}$; laser strength, $580 \mathrm{~mW}$; room temperature) . ${ }^{23)}$

PEG-MA のみならず様々な NHS 基を有する機能 性分子の導入が可能である。こうして作られたプ ローブは Fig. 11 に示すように integrin $\alpha_{\mathrm{V}} \beta_{3}$ を多く 発現している U87MG 細胞に特異的に蛍光性を付 与できることが示された.

6-4. リポソームへの RED-CNP の包含 Figure 6 のスキーム (d) に示したのは, リポソームに REDCNP を包含するスキームである. リポソームはド ラッグデリバリーなどにおいて既によく用いられて いる材料だが，血中滞留性の高い蛍光プローブを作 製する目的や，リポフェクションにより蛍光体を細 胞内へ送り込む目的，さらにはドラッグデリバリー そのものの挙動を in vivo 蛍光イメージングにより 追跡する目的でも RED-CNP を包含することで様 々な応用が期待される。筆者らはまず，粒径約 150 $\mathrm{nm}$ の $\mathrm{Er}$ ドープ $\mathrm{Y}_{2} \mathrm{O}_{3}$ ナノ粒子に分散安定性の付与 を目的として PEG- $b$-PAAc による PEG 修飾を施 
(a)

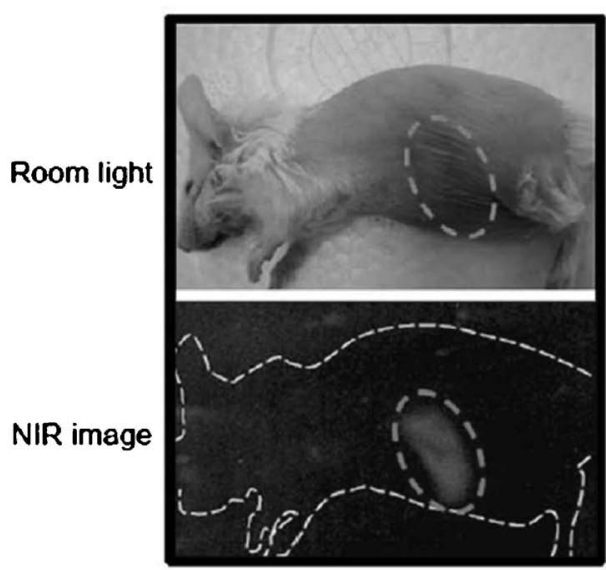

(b)

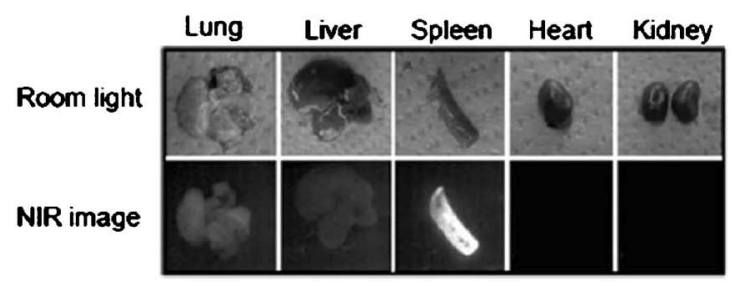

Fig. 10. in vivo Near-Infrared Imaging of Living Mouse with Intravenous Injection of PEG-YNPs

(a) Whole body and (b) various organs (emission measurement: room temperature; excitation wavelength, $980 \mathrm{~nm}$; laser strength, $700 \mathrm{~mW}$ $\left.\mathrm{cm}^{-2}\right) .{ }^{24)}$

し，これを分散した HEPES バッファーを用いて water-in-oil（W/O）エマルジョンを作製し，さら に複合エマルジョン法でアニオン性, カチオン性, PEG 修飾の 3 種の RED-CNP 内包リポソームを作 製した. ${ }^{27)}$ Table 1 にリポソームの組成を，Fig. 12 には得られた RED-CNP 内包リポソームのSEM 画 像を示す． Er ドープ $\mathrm{Y}_{2} \mathrm{O}_{3}$ ナノ粒子がリポソームに 内包されていることがわかる. Figure 13 に示すよ うに蛍光顕微鏡を用いると, リポソームから UC 発 光, NIR 発光ともに良好な蛍光が観察された. $P E G$ 化（PEGylation）したリポソームを作製する際に は，さらにDPPE-biotin を混合することでビオチ ンによるアビジンへの特異吸着性の付与を試みた。

Figure 14 に Er ドープ $\mathrm{Y}_{2} \mathrm{O}_{3}$ ナノ粒子, PEG 化リポ ソーム, PEG 化リポソームにビオチンを導入した リポソームについて，アビジンプレートを用いたプ レートアッセイにより特異吸着能を評価した結果を 示す. Er ドープ $\mathrm{Y}_{2} \mathrm{O}_{3}$ ナノ粒子は, アビジンプレー トとコントロールとして使用した BSA プレートに 非特異的に吸着するのに対し, PEG 化のみを行っ たリポソームではいずれとも相互作用しない. PEG とビオチンをリン脂質を用いてリポソーム表 (a) U87MG with more Integrin $\alpha_{\mathrm{T}} \cdot \beta_{3}$

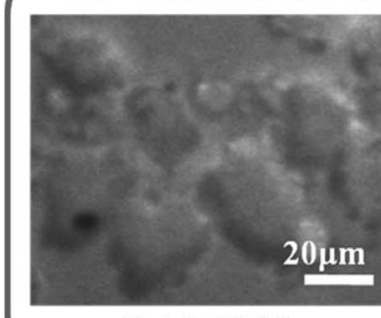

Bright Field

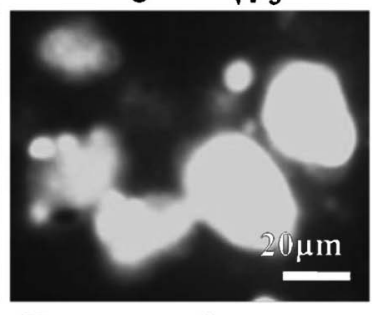

Fluorescence Image (b) MCF7 with less Integrin $\alpha_{1} \beta_{3}$

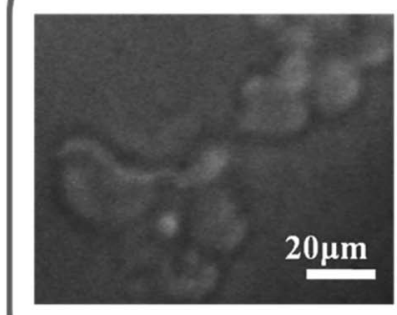

Bright Field

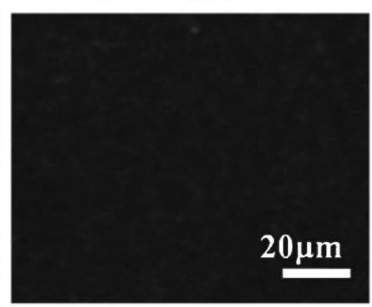

Fluorescence Image
Fig. 11. in vitro Staining of Human Glioblastoma U87MG (High Integrin $\alpha_{\mathrm{V}} \beta_{3}$ Expression) and Human Breast Cancer MCF-7 (Integrin $\alpha_{\mathrm{V}} \beta_{3}$ Negative) Using RGD-modified Nanoparticles (RGD-PEG-Er- $\mathrm{Y}_{2} \mathrm{O}_{3}$ )

Staining of U87MG with unmodified PEG-Er- $\mathrm{Y}_{2} \mathrm{O}_{3}$ nanoparticles is also shown as a control. All fluorescence images were acquired under the same condition and displayed under the same scale. The nanoparticles were excited using an IR laser $\left(\lambda_{\mathrm{ex}}=980 \mathrm{~nm}\right)$ and an upconversion emission between 660 and $740 \mathrm{~nm}$ was observed. The scale bar represents $20 \mu \mathrm{m} .{ }^{24)}$

Table 1. Composition of Solution for the Liposome Injected to Mouse ( $\mathrm{mol} \%)$

\begin{tabular}{ccccc}
\hline \hline Liposome & DPPC & Cholesterol & Additive & Amount \\
\hline Anionic & 40 & 40 & DPPG & 20 \\
Cationic & 40 & 40 & Stearylamine & 20 \\
PEGylated & 50 & 40 & PEG-DSG & 10 \\
\hline
\end{tabular}

面に導入することにより，BSA プレートには吸着 せず，アビジンプレートにのみ吸着する RED-CNP 内包リポソームが得られたことがわかる.

上記の方法で得られたリポソームのうちアニオン 性表面のリポソームは負に帯電した細胞とは相互作 用しないのに対し，カチオン性表面のリポソームを 用いると負に帯電した細胞と融合し, リポフェクシ ヨンにより $\mathrm{Er}$ ドープ $\mathrm{Y}_{2} \mathrm{O}_{3}$ ナノ粒子を細胞内部に 送り込むことができる. ${ }^{28)}$ Figure 15 は PEG 修飾を 施した Er ドープ $\mathrm{Y}_{2} \mathrm{O}_{3}$ ナノ粒子と未修飾の Er ドー プ $\mathrm{Y}_{2} \mathrm{O}_{3}$ ナノ粒子をそれぞれカチオン性リポソーム 


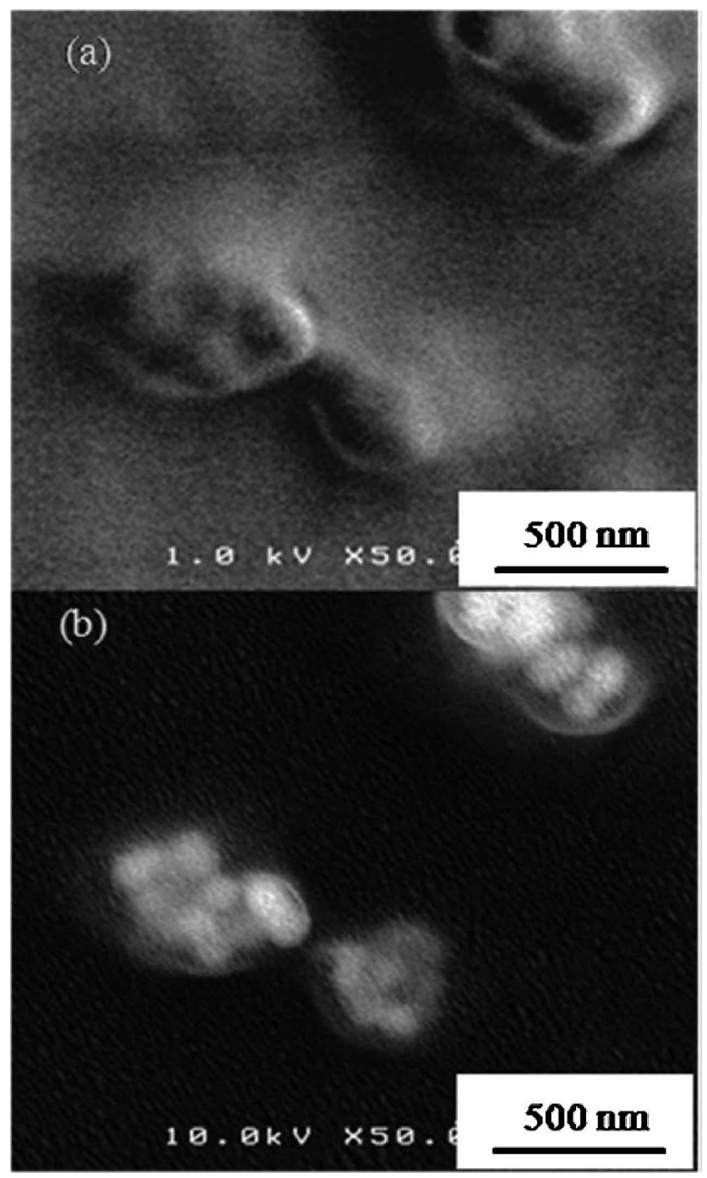

Fig. 12. FE-SEM Images of Liposome Encapsulating $\mathrm{Y}_{2} \mathrm{O}_{3}$ : $\mathrm{Er}^{3+}$ Nanoparticles

Accelerating voltages are (a) $1 \mathrm{kV}$ and (b) $10 \mathrm{kV} .{ }^{25)}$

に内包し，Huh-7 細胞にリポフェクションした結 果である．細胞を十分に洗浄した後でも NIR 蛍光 が観察されたことから Er ドープ $\mathrm{Y}_{2} \mathrm{O}_{3}$ ナノ粒子は 細胞内部に取り込まれていると考えられ，今後細胞 内部でのナノ粒子の挙動や, 小動物体内での細胞の 挙動の追跡に有用な蛍光性の細胞が得られたと考え られる。

現在報告されている方法で，多くの場合 $\mathrm{Y}_{2} \mathrm{O}_{3}$ ナ ノ粒子は親水性溶媒中に分散した状態で得られるの に対し， $10 \mathrm{~nm}$ 程度の粒径の $\mathrm{Er}$ ドープ $\mathrm{NaYF}_{4}$ は疎 水性溶媒に分散した状態で得ることができる. ${ }^{20)}$ 筆 者らはこの性質を利用して, Er ドープ $\mathrm{NaYF}_{4}$ をリ ン脂質二重層の疎水性膜内に取り込むことで，脂質 膜内に粒径約 $10 \mathrm{~nm}$ の $\mathrm{Er}$ ドープ $\mathrm{NaYF}_{4}$ を内包し た粒径約 $110 \mathrm{~nm}$ の PEG 化リポソームと, 水層内 に粒径約 $140 \mathrm{~nm}$ の $\mathrm{Er}$ ドープ $\mathrm{Y}_{2} \mathrm{O}_{3}$ ナノ粒子を内包 した粒径約 $450 \mathrm{~nm}$ の PEG 化リポソームを作製 し，マウス体内での挙動を OTN-NIR in vivo 蛍光

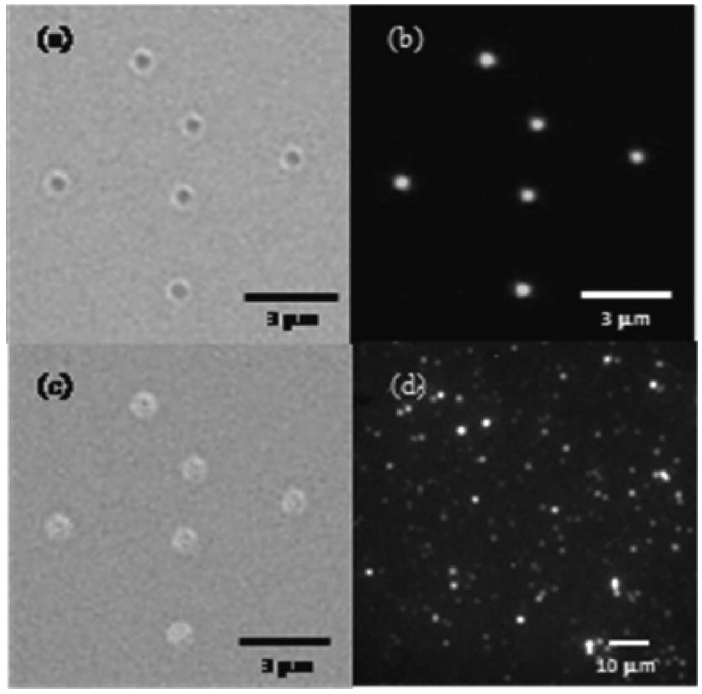

Fig. 13. Fluorescence Microscope Images of Liposome Encapsulating $\mathrm{Y}_{2} \mathrm{O}_{3}: \mathrm{Er}^{3+}$ Nanoparticles

Imaging schemes are (a) bright filed image, (b) UC fluorescence image, (c) (a) + (b) and (d) NIR fluorescence image. ${ }^{25}$

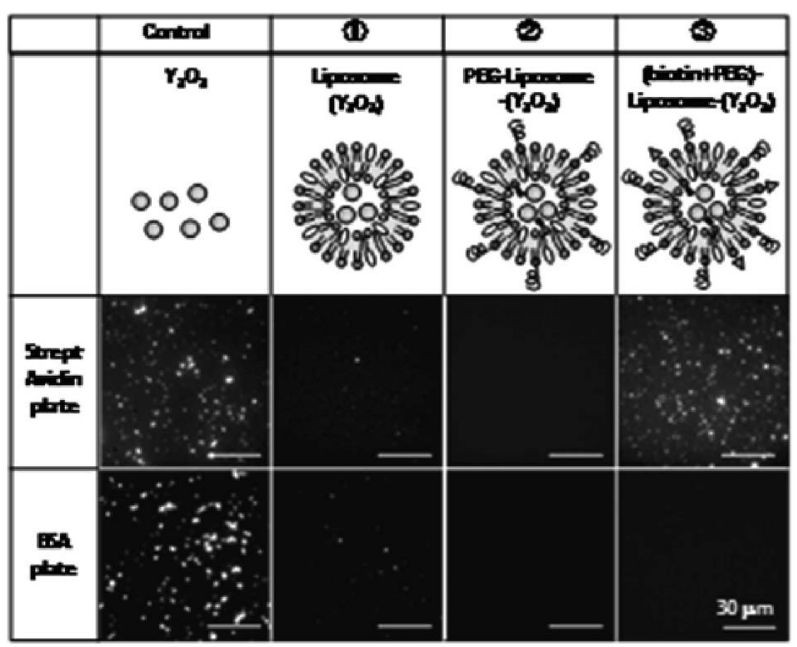

Fig. 14. Evaluation of the Specific Interaction of Liposome Encapsulating $\mathrm{Y}_{2} \mathrm{O}_{3}: \mathrm{Er}^{3+}$ Nanoparticles by Fluorescence Plate Assay on Strept Avidin and BSA Plates

Bare $\mathrm{Y}_{2} \mathrm{O}_{3}: \mathrm{Er}^{3+}$ nanoparticles, liposome, liposome modified with PEG, and liposome modified with PEG and biotin were compared. ${ }^{25)}$

イメージングシステムで観察した. ${ }^{15)}$ Figure 16 に それぞれの粒子と粒子内包リポソームの SEM 像を 示す。得られたリポソームをマウスの尾静脈から注 射した後， 1 時間及び 24 時間の OTN-NIR in vivo 蛍光イメージング画像を Fig. 17 に示す。リポソー ムの粒径により経時的な肝臓への集積が異なってい ることがわかる.

以上のように RED-CNP 内包リポソームは，粒 径制御が可能で, リン脂質膜表面に様々な機能性の 

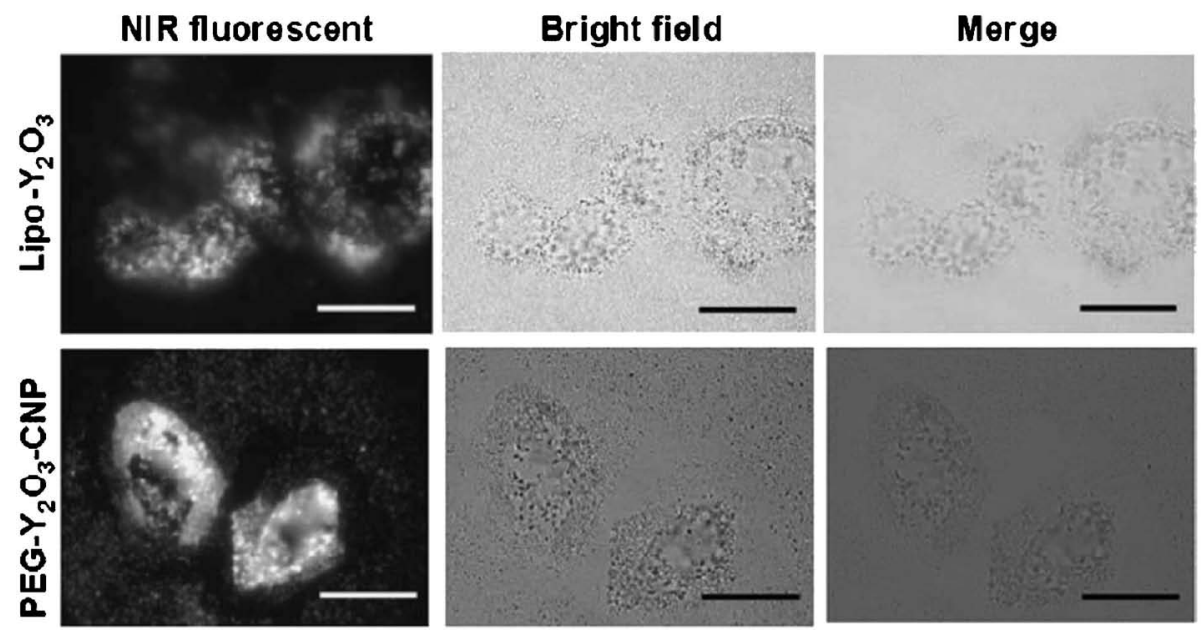

Fig. 15. Detection of Lipo- $\mathrm{Y}_{2} \mathrm{O}_{3}$ in the Intracellular Region of Cancer Cells

Huh-7 cells were incubated with $0.05 \mathrm{mg} / \mathrm{mL}$ Lipo- $\mathrm{Y}_{2} \mathrm{O}_{3}$ or PEG- $\mathrm{Y}_{2} \mathrm{O}_{3}$-CNP at $37^{\circ} \mathrm{C}$ for $6 \mathrm{~h}$. The cells were examined under a fluorescence microscope equipped with a $980 \mathrm{~nm}$ laser diode for the NIR excitation source. Scale bars represent $30 \mu \mathrm{m} .{ }^{26)}$

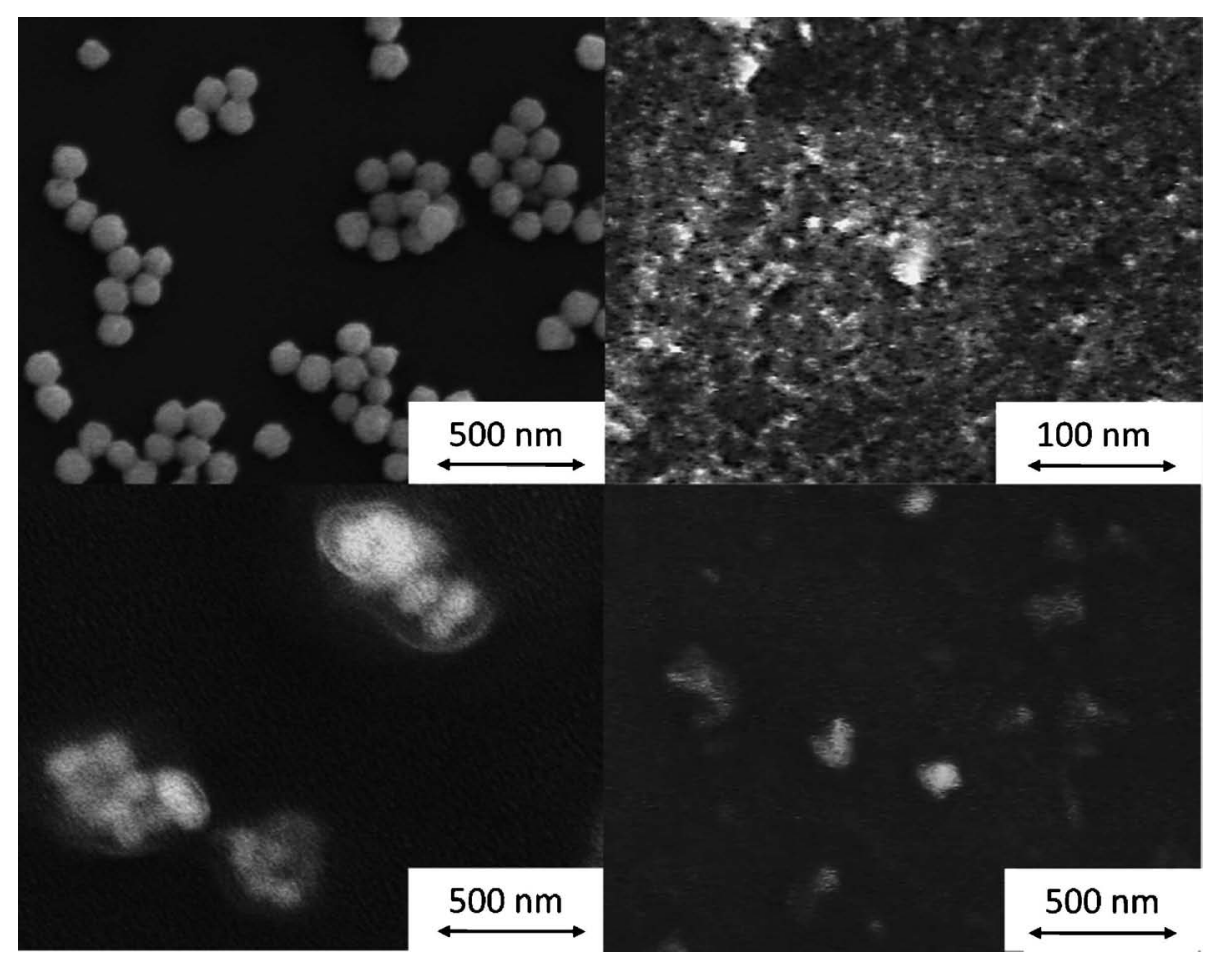

Fig. 16. FE-SEM Images of (a) $\mathrm{Y}_{2} \mathrm{O}_{3}: \mathrm{Er} / \mathrm{Yb}$ Nanoparticles, (b) $\mathrm{NaYF}_{4}$ : Er/Yb Nanoparticles, (c) $\mathrm{Y}_{2} \mathrm{O}_{3}-\mathrm{Lipo}$ and (d) NaYF : Lipo ${ }^{15)}$

分子や高分子を導入することが可能なだけでなく, リポフェクションにより RED-CNPを細胞内に送 達することが可能なため, バイオイメージングの様 々なシーンにおいて有用な材料であると考えられる.

7. OTN-NIR 蛍光バイオイメージングのメディ カル応用

これまでの研究で, OTN-NIR 蛍光を用いると, 数 $\mathrm{cm}$ の動物組織を透過した蛍光イメージングが可
能であることが示された. ${ }^{29)}$ 筆者らはこの高い生体 透過性の医療への応用に取り組んでいる。硬性内視 鏡である腹腔鏡を用いた手術は，患者に対し低侵襲 な外科手術の方法として一般化しつつあるが，大腸 がんの手術においては，軟性内視鏡を用いて大腸内 部から患部をマーキングし，硬性内視鏡を用いて大 腸外部の腹腔から患部を切除する手術が行われてい る。現在マーキングには墨汁が用いられている．墨 


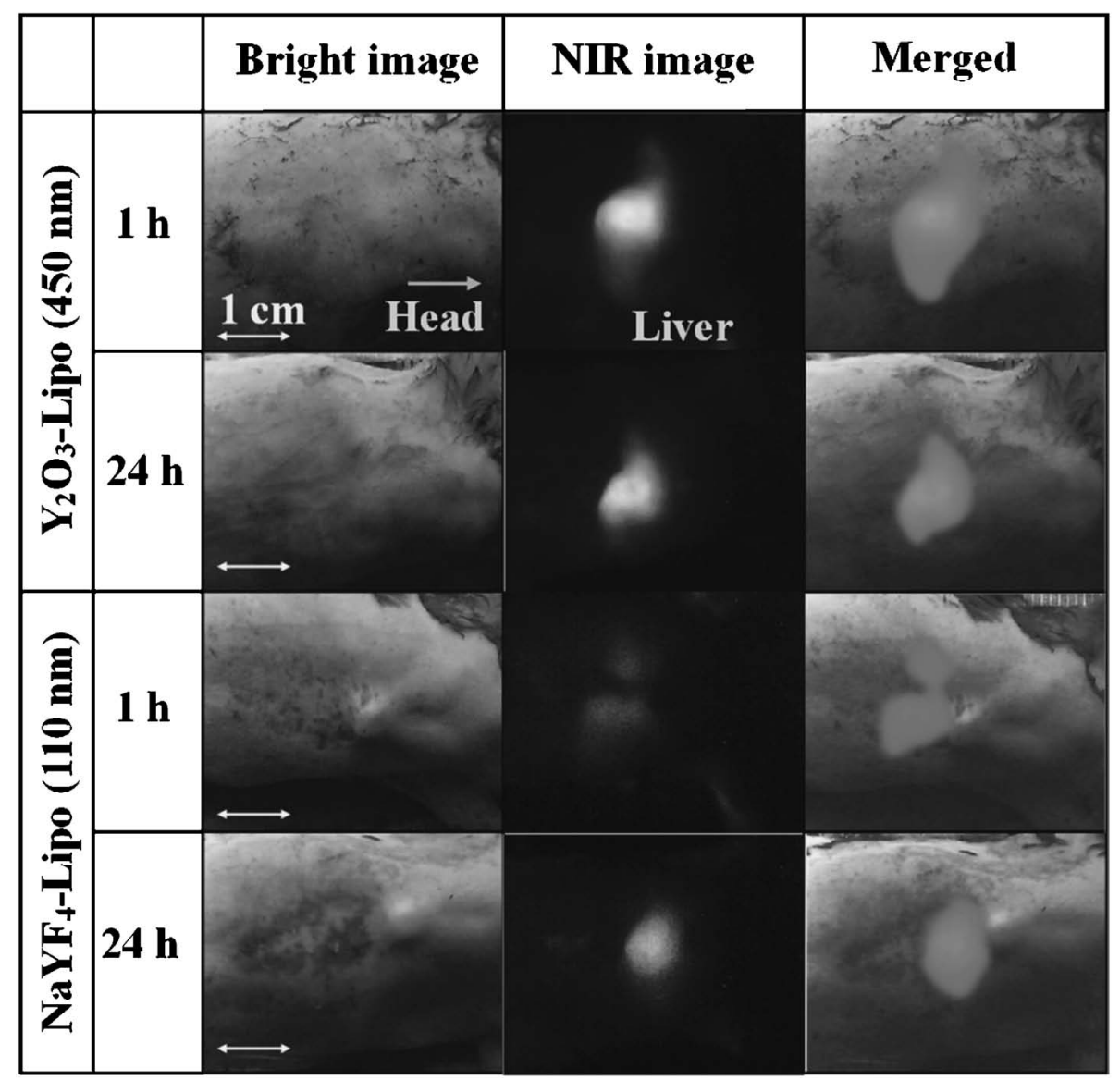

Fig. 17. in vivo OTN-NIR Fluorescence Images of Mice at $1 \mathrm{~h}$ or $24 \mathrm{~h}$ after Injection of $\mathrm{Y}_{2} \mathrm{O}_{3}$-Lipo and $\mathrm{NaYF}_{4}$-Lipo Excitation and emission wavelengths are 980 and $1550 \mathrm{~nm}$, respectively. ${ }^{15)}$

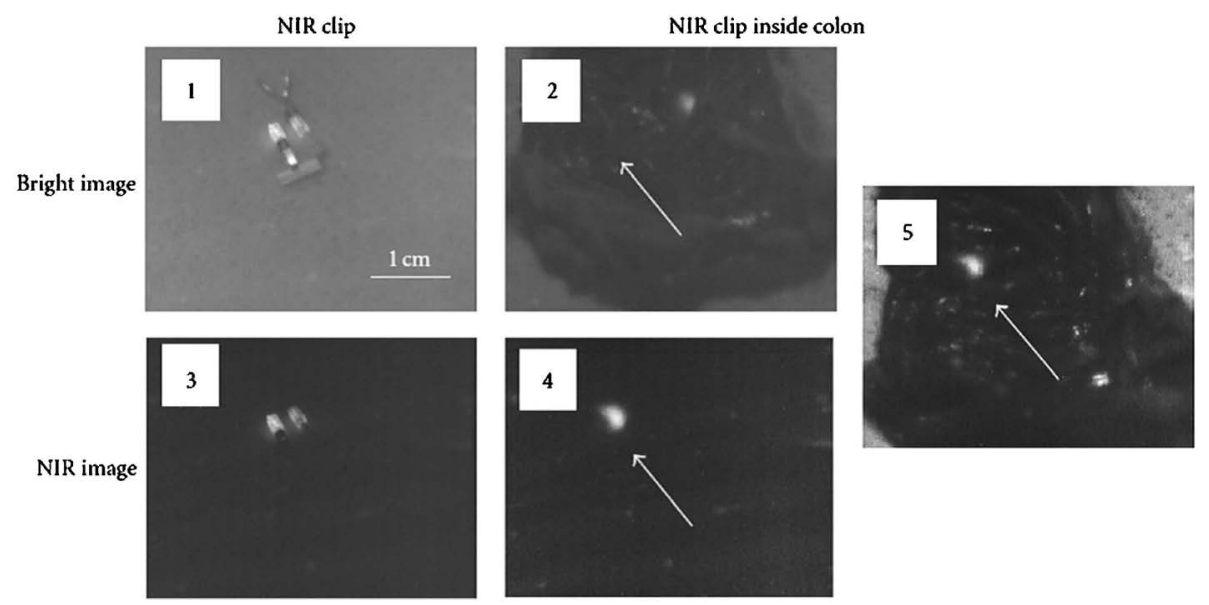

Fig. 18. NIR Fluorescent Clips

Bright-field $(1,2)$ and NIR fluorescence $(3,4)$ images of $\mathrm{Y}_{2} \mathrm{O}_{3}$ : YbEr-nanoparticle-coated clips $(1,3)$ and those set inside swine colon $(2,4)$. Observations of (2) and (4) are from outside of the colon. Hybrid image of the $\mathrm{Y}_{2} \mathrm{O}_{3}$ : YbEr- nanoparticle -coated clips set in swine colon (5) is shown. Arrows in (2), (4) and (5) show the position of the clip inside swine colon.

は腸壁を拡散する性質があるために，大腸内部から 軟性内視鏡を用いて注射すると患部が染色され，墨 が大腸外部まで拡散するために腹腔鏡により大腸外 部から患部の特定が可能である。しかし，これは墨
の腸壁における高い拡散能を利用している以上，患 部周辺に広がりを持つことは避けようがなく, さら に小領域で視認性の高いマーキング方法の開発が望 まれている，筆者らは OTN-NIR 蛍光を示す RED- 
CNP を大腸がんのマーキング剂として用い，OTNNIR の観察が可能な腹腔鏡を用いて患部を特定 し，より正確で小領域の切除が可能な技術の開発に 取り組んでいる. ${ }^{30)}$ Figure 18 に示したのは内視鏡 用のクリップに NIR 蛍光体を付与して豚の大腸内 部に埋み, InGaAs CCD カメラで腸の外部からイ メージングを行った例である。損失の少ない NIR 蛍光は大腸の外部からでも明瞭に観察することがで き，今後新たな大腸がんのマーキングの手段として の更なる開発が期待される.

\section{8. まとめ}

生体試料で高い光透過性を持つ OTN-NIR 波長域 における新たな蛍光バイオイメージングの, 蛍光プ ローブとシステムの開発について紹介した。特に in vivo イメージングにおいては従来の数 $\mathrm{mm}$ を遥 かに上回る数 $\mathrm{cm}$ の観察深度が達成され, 次世代の 蛍光イメージングの波長域として大いに期待され る。 また，この波長域における蛍光体として REDCNP は有用であり，様々な表面修飾やリポソーム への包含により, 生命, 薬学研究領域や医療への応 用が広がりつつある.

\section{REFERENCES}

1) "Application of Quantum Dot in Life Science," ed. by Yamamoto S., CMC Publishing CO., LTD., Tokyo, 2007.

2) Schaafsma B. E., Sven J., Mieog D., Hutteman M., van der Vorst J. R., Kuppen P. J. K., Löwik C. W. G. M., Frangioni J. V., van de Velde C. J. H., Vahrmeijer A. L., J. Surg. Oncol., 104, 323-332 (2011).

3) $\mathrm{Ma}$ Q., Su X., Analyst, 135, 1867-1877 (2010).

4) “Iyou Butsurigaku," eds. by Iinuma T., Inaba S., Fujiwara H., Ishiyaku Publishers, Inc., Tokyo, 1998, p. 162.

5) Anderson R. R., Parrish P. A., J. Invest. Dermatol., 77, 13-19 (1981).

6) Kushida T., "Hikari Bussei Butsurigaku," Asakura Publishing Co., Ltd., Tokyo, 1991.

7) Soga K., "Nanostructured Materials for Biomedical Applications," eds. by Tan M. C., Chow G. M., Ren L., Transworld Research Network Publishers, New Delhi, 2009, pp. 223 -241 .
8) Powell R. C., "Physics of Solid State Laser Materials," Springer, New York, 1998.

9) "Optical Fiber Amplifiers: Materials, Devices, and Applications," ed. by Sudo S., Artech House Publishers, Norwood, 1997.

10) Soga K., Dojin News, 141, 6-11 (2012).

11) Soga K., Kamimura M., Nagasaki Y., Oyo Buturi, 77, 1458-1461 (2008).

12) Soga K., Bunseki, 37-44 (2012).

13) Zijlmans H. J. M. A. A., Bonnet J., Burton J., Kardos K., Vail T., Niedbala R. S., Tanke H. J., Anal. Biochem., 267, 30-36 (1999).

14) Soga K., Bunseki Kagaku, 58, 461-471 (2009).

15) Soga K., Tokuzen K., Fukuda K., Hyodo H., Hemmer E., Venkatachalam N., Kishimoto H., J. Photopolym. Sci. Technol., 25, 57-62 (2012)

16) Alexis F., Pridgen E., Molnar L. K., Farokhzad O. C., Mol. Pharm., 5, 505-515 (2008).

17) Nishiyama N., Kataoka K., Adv. Polym. Sci., 193, 67-101 (2006) .

18) Venkatachalam N., Saito Y., Soga K., J. Am. Ceram. Soc., 92, 1006-1010 (2009).

19) Konishi T., Shimizu M., Kameyama Y., Soga K., J. Mater. Sci. Mater. Electron., 18, S183S186 (2007).

20) Wang L., Li Y., Chem. Mater., 19, 727-738 (2007)

21) Soga K., J. Jpn. Soc. Biomater., 29, 95-103 (2011).

22) Soga K., "Encyclopedia of Advanced Biomaterials," NTS Inc., Tokyo, 2012, pp. 482485.

23) Kamimura M., Miyamoto D., Saito Y., Soga K., Nagasaki Y., Langmuir, 24, 8864-8870 (2008)

24) Kamimura M., Kanayama N., Tokuzen K., Soga K., Nagasaki Y., Nanoscale, 3, 37053713 (2011).

25) Zako T., Nagata H., Terada N., Sakono M., Soga K., Maeda M., J. Mater. Sci., 45, 53255330 (2008).

26) Zako T., Nagata H., Terada N., Utsumi A., Sakono M., Yohda M., Ueda H., Soga K., Maeda M., Biochem. Biophys. Res. Commun., 381, 54-58 (2009).

27) Soga K., Tokuzen K., Tsuji K., Yamano T., Hyodo H., Kishimoto H., Eur. J. Inorg. Chem., 2673-2677 (2010). 
28) Akiyama H., Tokuzen K., Otsuka H., Soga K., Tashiro F., J. Phys. Conf. Ser., 232, 012001 (2010).

29) Soga K., Tokuzen K., Tsuji K., Yamano T., Venkatachalam N., Hyodo H., Kishimoto H.,
Proc. SPIE, 7598, 759807-1-9 (2010).

30) Zako T., Hyodo H., Tsuji K., Tokuzen K., Kishimoto H., Ito M., Kaneko K., Maeda M., Soga K., J. Nanomater., 1-8 (2010). 